\title{
Interleukin 5 Measurement
}

National Cancer Institute

\section{Source}

National Cancer Institute. Interleukin 5 Measurement. NCI Thesaurus. Code C74833.

The determination of the amount of interleukin 5 present in a sample. 